\title{
Malignus lágyrésztumor eltávolítás után szabadon maradt Achilles íntükör fedése
}

Esetismertetés

DR. MOGHADDAM AMIN MAYSAM, DR. KISS JÁNOS, DR. PERLAKY TAMÁS, DR. SZENDRŐI MIKLÓS

\section{ÖSSZEFOGLALÁS}

Az Achilles ín feletti lágyrészdefektus gyakran az Achilles ín szakadása vagy fekély következtében kialakuló bőrnekrózis eredménye, sebfertőzéssel vagy anélkül. Ezen kívül az Achilles ín feletti lágyrészdaganatok és malignus bőrtumorok ( $\mathrm{pl}$. melanoma, laphám carcinoma) kimetszése után, illetve termikus sérülések (égés) esetén is maradhatnak vissza nagyméretú lágyrészdefektusok. Ezek rekonstrukciója kihívást jelent a sebészek számára, különösen az időskorú betegeknél, rossz vérkeringési viszonyok mellett. A plasztikai sebészeti megoldások gyakran sikertelenek, a rossz vérkeringési viszonyok és a szabadon maradt Achilles íntükör miatt. A rekonstrukciós lehetőségek közé tartozik a keresztezett lebenyplasztika, szabad lebeny átültetés, irha pótlása acellularis dermal matrix használatával, és a vákuumkezelés utáni félvastag bőrátültetés. Dolgozatunk célja egy enormis méretű malignus lágyrész szarkóma eltávolítása után szabadon maradt Achilles íntükör fedésének bemutatása. Ennek a területnek a fedésére az irodalomban sem találtunk egyértelmű sikeres megoldást. Plasztikai sebésszel történt konzultáció után a körülbelül $15 \mathrm{~cm}$ átmérőű, kör alakú szöveti defektus fedését, félvastag bőrátültetéssel, vákuumkezelés alkalmazása mellett végeztük el sikeresen.

\section{Kulcsszavak: $\quad$ Achilles ín; Félvastag börátültetés; Lágyrész rekonstrukció; Lágyrész tumor; Szarkóma; Vákuumkezelés;}

M. Moghaddam Amin, J. Kiss, T. Perlaky, M. Szendrői: Covering of a defect above Achilles tendon, after removal of soft tissue sarcoma. Case report

Soft tissue defect above the Achilles tendon is often the result of skin necrosis associated with Achilles tendon rupture or crural ulcer, with or without wound infection. In addition, after the removal of soft tissue sarcomas and malignant skin laesions (melanoma, squamous cell carcinoma), also after burn injuries, there are often large soft tissue defects above the Achilles tendon. These are challenging for surgeons in reconstructive surgery, especially in elderly patients, with poor blood circulation. Various plastic solutions are often unsuccessful due to poor blood circulation and free Achilles tendon. Reconstructive options include cross-leg flap, free vascularised musculocutan flap, using acellular dermal matrix and split thickness skin graft with vacuum assisted wound closure. From the point of view of plastic surgery, we did not find in the literature a clear, successful solution to cover this area. The aim of this article is to report on a case covering the Achilles tendon after the removal of a large sized malignant soft tissue sarcoma. After consultation with plastic surgeon, the circular shaped soft tissue defect with an approximately diameter of $15 \mathrm{~cm}$ was first treated by vacuum technique than the granulation tissue produced on the tendon surface was covered by split thickness skin graft.

\section{Keywords:}

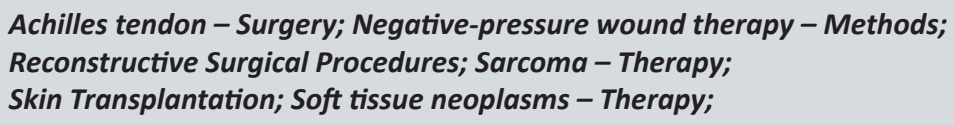




\section{BEVEZETÉS}

A lágyrész-szarkómák megjelenése ritka, gyakoriságuk 30-50 új eset/millió lakos/év, így az összes rosszindulatú daganatoknak csak mintegy $1-1,5 \%$-át teszik ki $(4,11)$. Biológiai viselkedésüket figyelembe véve a legújabb WHO beosztás három csoportot különböztet meg: benignus, intermedier (lokálisan agresszív vagy ritkán metasztatikus), valamint malignus természetűeket (4). A szövettani alcsoportokat tekintve a WHO több mint 40 eltérő entitást különböztet meg. A lágyrész-szarkómák az esetek kétharmadában az alsó végtagon fordulnak elö (4).

A Semmelweis Egyetem Ortopédiai Klinika lágyrész daganat regiszterének adatai alapján nem volt szignifikáns különbség a két nem között a gyakoriságot tekintve, a betegek átlagéletkora 52,36 évnek bizonyult. A leiomyoszarkóma volt az egyik leggyakoribb alcsoport, a liposzarkóma, szinovialis szarkóma, mixofibroszarkóma és malignus fibrózus hisztiocitóma (MFH) mellett, incidenciája az 5. és 8. évtizedben volt a legmagasabb (8).

$\mathrm{Az}$ ép sebészi széllel történő széles reszekció továbbra is a legfontosabb a lágyrészszarkómák kezelésében, gyakran azonban kiterjedt bőr- és lágyrészdefektusok maradnak vissza. A különböző plasztikai sebészeti technikák célja, hogy csökkentsék az adott terület funkcionális károsodását és fedjék a szöveti hiányokat, kritikus anatómiai struktúrákat, ezáltal javítsák a betegek életminőségét (10). $A z$ ép sebészi szél elérése azonban az Achilles ín felett nehézséget jelenthet a plasztikai sebészeti rekonstrukcióban, mivel nagy kiterjedésű csupasz íntükör maradhat vissza, amelyen nem tapad meg a tumor eltávolításával egy időben átültetett félvastag bőr. Ennek a területnek a fedésére az irodalomban sem találtunk egyértelműen ajánlott módszert.

Esetünkben a 63 éves nőbetegnél enormis méretű, malignus lágyrésztumor eltávolítását végeztük el a bal lábszáron, az Achilles ín feletti területen. $A z$ aspirációs citológia grade 3 leiomyoszarkómát igazolt. Onkológiai szempontból magas lábszár amputáció lett volna a legbiztonságosabb kezelési lehetőség a radikalitást illetően, viszont a beteg ezt nem fogadta el, emiatt marginális tumoreltávolítás mellett döntöttünk. A lábszár distalis végén, nagyméretű lágyrészdaganatok esetén, a végtagmegtartó radikális mútét nehezen elvégezhető, mivel $2 \mathrm{~cm}$ távolság szükséges a daganattól. Az esetek nagy részében ebben a lokalizációban végtagmegtartó mútét csak marginális eltávolítás mellett végezhető el (a reszekciós sík kevesebb, mint $2 \mathrm{~cm}$ a tumortól), mivel a daganat mérete és kiterjedése a környező lágyrészek rekonstrukcióját nehezíti, emiatt sok esetben a radikalitás szempontjából az amputáció a legjobb mútéti technika onkológiai értelemben. A mútét során, a tumornak az épben, marginálisan történő eltávolítása után az Achilles íntükör teljes felszíne szabadon maradt. Plasztikai sebésszel történt konzultációk után a $15 \mathrm{~cm}$ átmérőjü, kör alakú szöveti defektusra vákuum készüléket helyeztünk fel, majd megfelelő granulációs szövet kialakulása után, két lépésben, félvastag bőrátültetést végeztünk. Az Achilles ín rövidülésének kivédése érdekében gipszrögzítést alkalmaztunk. Gyógyulás után a boka mozgásaiban elmaradást vagy az Achilles ínon kontraktúrát nem észleltünk. A beteg záró kontrollvizsgálata során onkológiai státusza negatívnak bizonyult, az MRI felvételek alapján recidíva nem volt látható, jelenleg panaszmentes.

\section{ESETISMERTETÉS}

A 63 éves nőbeteget 2014. októberében vizsgáltuk első alkalommal, bal Achilles ín feletti lágyrész elváltozás miatt. Elmondása szerint akkor már több mint két éve észlelte az elváltozást, amely lassan növekedett, viszont orvoshoz nem fordult. Akkor a bal Achilles ín feletti régióban enormis méretű és exofitikus növekedésű lágyrésztumor volt látható (1. ábra). 


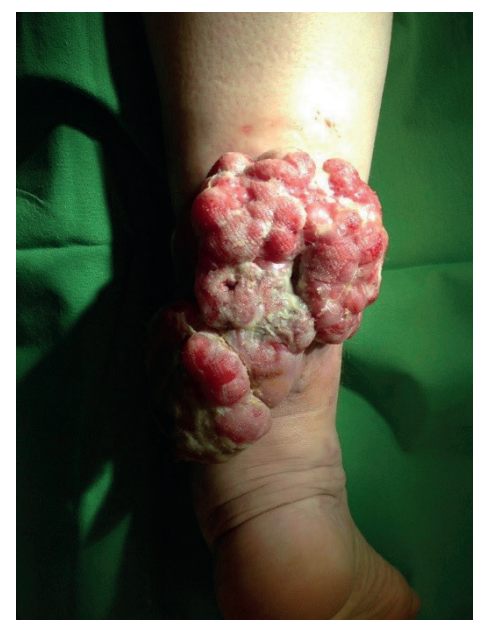

1. ábra

Exofitikus terjedésü lágyrésztumor a lábszár dorsalis oldalán az Achilles in felett.

A beteg kivizsgálása során aspirációs citológiai és MRI vizsgálatot végeztünk. Az aspirációs citológiai vizsgálat grade 3 leiomyoszarkómát igazolt. Az MRI felvételeken a $14 \times 8 \times 9 \mathrm{~cm}$ tumor felületesen, exofitikus helyzetben helyezkedett el az Achilles ín felett, nem törte át a felületes fasciát, a subcutan réteget destruálta (2. $a-b$ ábra).
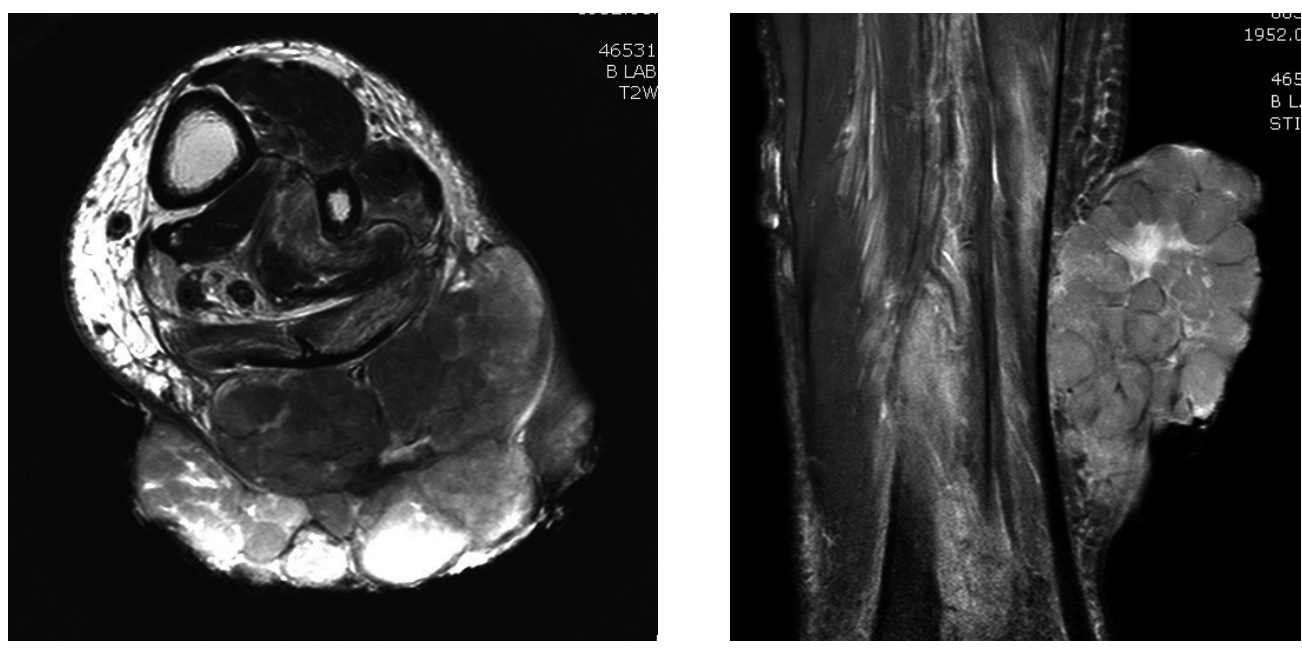

\section{2. ábra}

a) T2 súlyozású MRI felvétel

b) T1 súlyozású MRI felvétel Exofitikus terjedésü lágyrésztumor az Achilles ín felett, a felületes fascia ép, a subcutan réteg destruált. 
A szövettani diagnózis alapján a tumor eltávolítását - az onkológiai radikalitást figyelembe véve - messze az épben, csak magas lábszár amputációval lehetett volna elérni. A beteget erre vonatkozóan felvilágosítottuk, aki ennek ellenére az amputációba nem egyezett bele, emiatt a tumor marginális eltávolítását terveztük. A tumor körül 1-2 cm széles ép

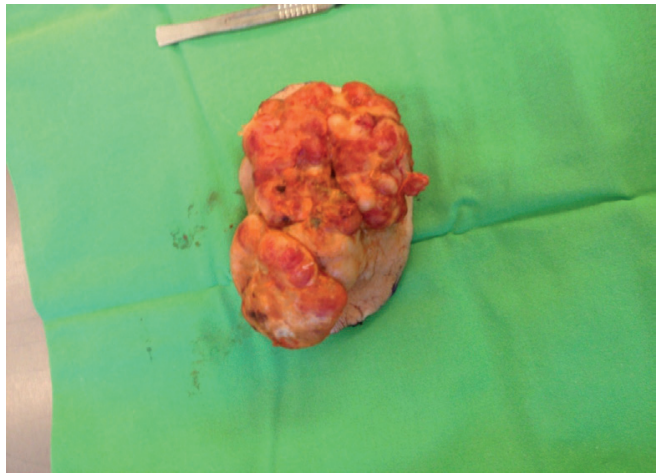

bőrt hagytunk, majd mivel az MRI felvételeken az Achilles ín nem volt érintett mélységben, a tumort az inat körülvevő paratenon dorsalis részével eltávolítottunk. Az Achilles ín makroszkóposan épnek bizonyult, az íntükör teljes felszíne a paratenon hiányában szabadon maradt (3. $a-b$ ábra).

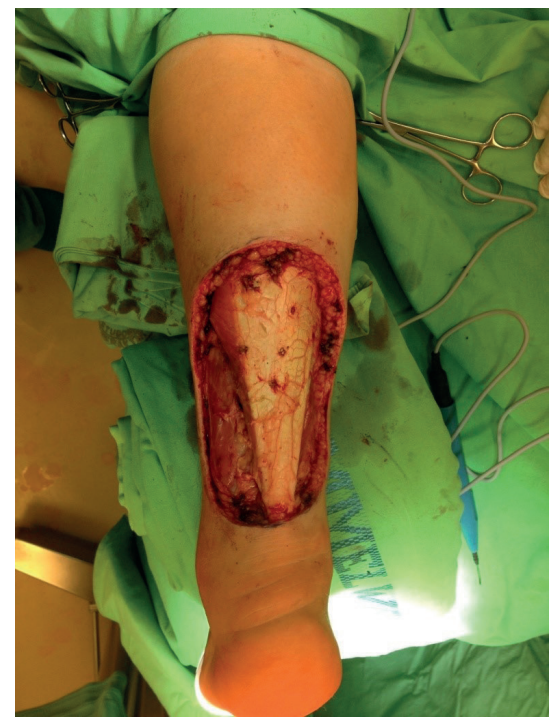

\section{3. ábra}

a) Az eltávolított tumor makrofotója az ép szélekkel b) A visszamaradt sebalap a szabadon maradt Achilles intükörrel

A tumor eltávolítását követően a defektus területére vákuumkezelést alkalmaztunk. A felhelyezett vákuumot ötnaponta, mútéti körülmények között cseréltük. Az első két hetet követően a sebszéleken körkörösen granulációs szövet alakult ki, az Achilles ín felett azonban változást még nem észleltünk, az ínfelszín továbbra is szabadon maradt (4. a ábra).

A mútét során eltávolított daganatszövet részletes szövettani vizsgálata szintén grade 3 leiomyoszarkómát igazolt, a daganat eltávolítása az épben történt, helyenként a daganat a sebészi széleket kevesebb, mint $1 \mathrm{~mm}$-re megközelítette.

Két hét vákuumkezelés után plasztikai sebész javaslatára az Achilles inat több helyen hosszában „hálószerűen” behasítottuk, ezáltal lehetőséget adva arra, hogy az alatta lévő izomszövetből származó pluripotens őssejtek kötőszövetes réteget hozzanak létre az ín felszínén. Az ín két szélén, ahol granulációs szövet alakult ki (4. $b$ ábra), félvastag bőrt helyeztünk fel, majd tovább folytattuk a vákuumkezelést. Az Achilles ín rövidülésének megelőzése érdekében gipszrögzítést alkalmaztunk (rövid plantáris gipszsín). 

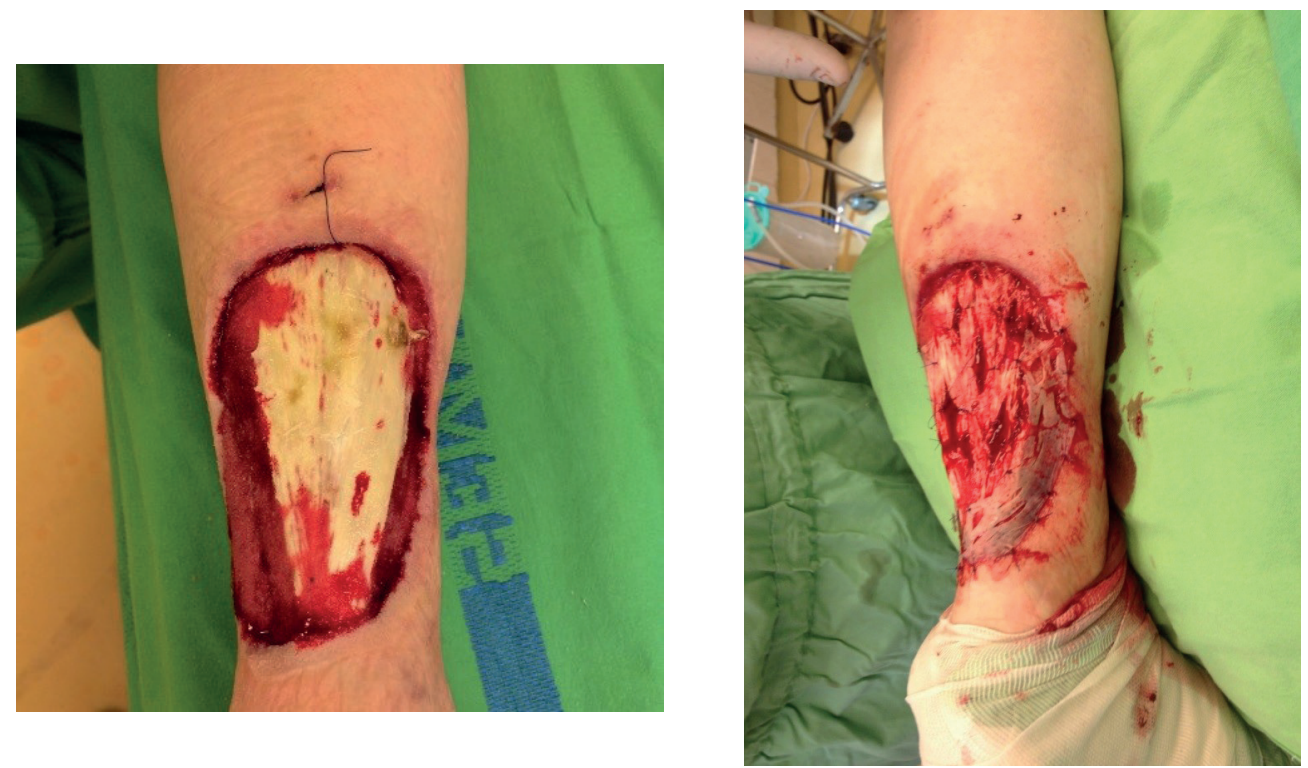

\section{4. ábra}

a) A sebalap 2 héttel az első mütét után: széli területen megindult a granulációs szövet képződés b) Részleges félvastag börplasztika a széli területen, illetve az Achilles ín hálószerü behasítása.

A második mútét után jó ütemben indult meg a granulációs szövet képződése az íntükrön a mélyebb rétegekból. Összesen hat hétig alkalmaztunk vákuumkezelést, gipszrögzítés mellett. Ez idő alatt viszonylag vastag és jól erezett granulációs szövet alakult ki az Achilles ín teljes felszínén (5. $a-b$ ábra).
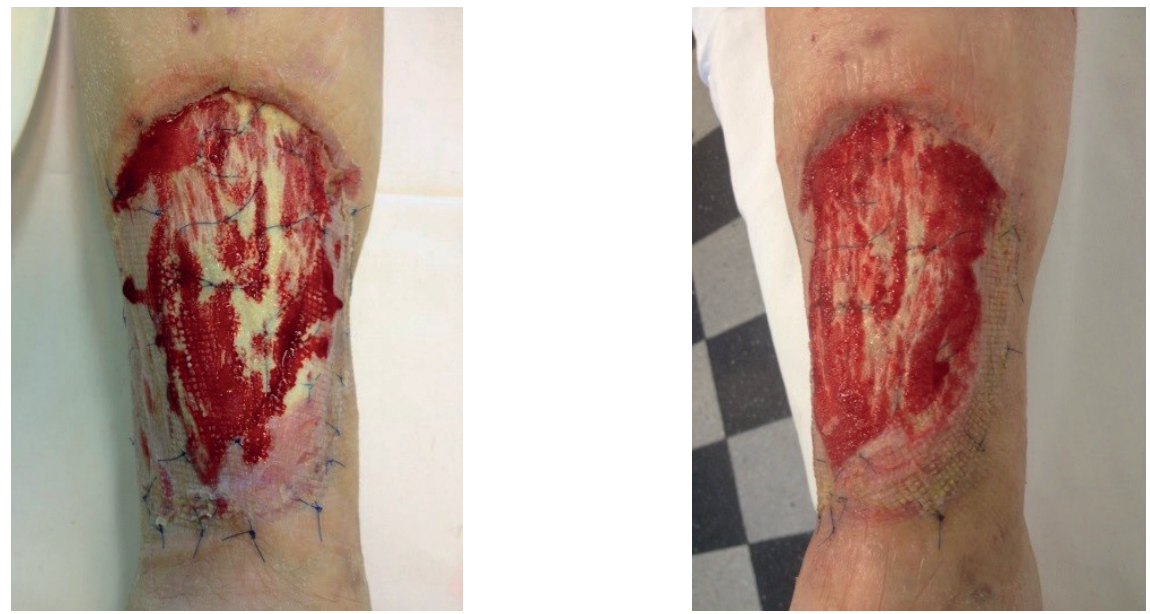

\section{5. ábra}

Granulációs szövet képződés 4 héttel

(a) illetve 6 héttel

(b) a vákuum kezelést követően. 
A hat hét vákuumkezelést követően újabb mútétet végeztünk, amely során az Achilles ín feletti területet is félvastag bőrrel fedtük (6. ábra).

Ezt követően a félvastag bőrre további két hétig vákuumot helyeztünk fel (ötnaponkénti cserével) a jobb megtapadás érdekében, gipszrögzítést már nem alkalmaztunk. Öszszességében 8 héttel az első mútét után teljes gyógyulást értünk el, a boka mozgásaiban elmaradást, valamint az Achilles ínon kontraktúrát nem észleltünk (7. $a-b$ ábra).

Mútét után a beteg kemoterápiás kezelésben részesült, az utolsó kontrollvizsgálatkor, 42 hónappal mútét után, onkológiai státusza negatív volt, távoli metasztázis nem alakult ki, illetve a kontroll MRI felvételeken, mútéti területen recidívát nem észleltünk, fizikálisan az átültetet bőr zsugorodása nem volt észlelhető, az Achilles ínon kontraktúra nem alakult ki, a bokamozgásokban lényeges elmaradást nem észleltünk.

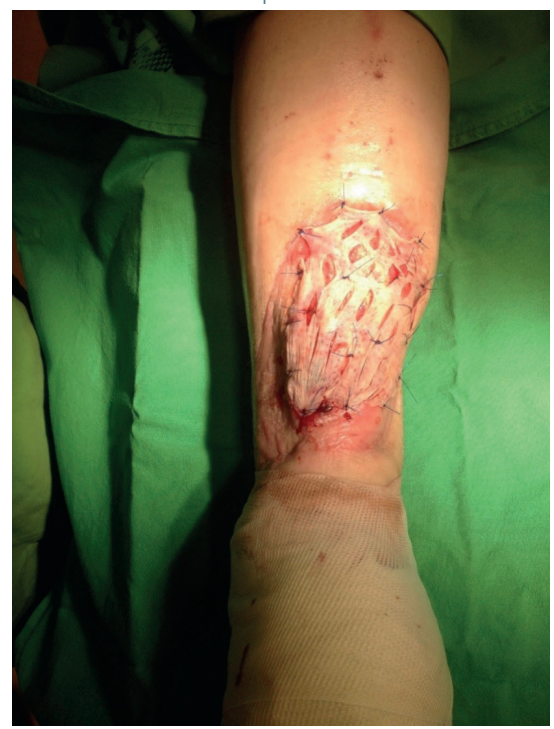

6. ábra

6 hét vákuumkezelés után az Achilles ín feletti területet is fedtük félvastag börrel

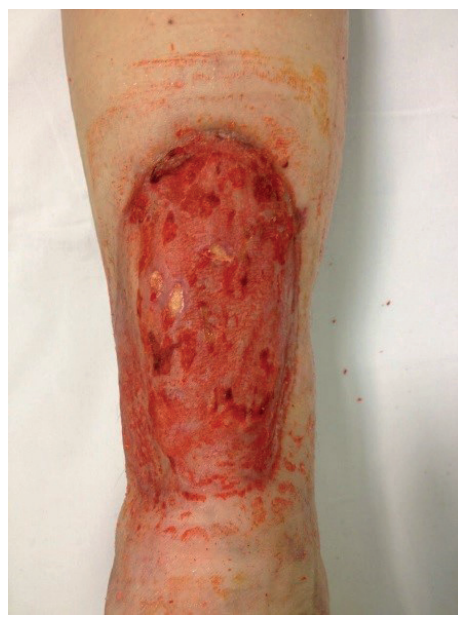

a) 10 héttel az első mütétet követöen

b) 7 hónappal később a mütéti terület képe félvastag bőrrel történő fedés után 


\section{MEGBESZÉLÉS}

Az Achilles ín feletti defektusok fedése nehézséget jelent, föleg idősebb betegeknél, a rosszabb vérkeringési viszonyok miatt. Plasztikai sebészeti szempontból ennek a területnek a fedésére az irodalomban egyértelmű, sikeres megoldást még nem közöltek.

Az irodalomban különböző típusú szabad lebenyek alkalmazását javasolják az Achilles ín feletti lágyrészdefektusok rekonstrukciójához. Ezek közé tartozik a radiális alkari lebeny a palmaris longus ínnal (5), a lateralis felkari lebeny a triceps ínnal (3), a dorsalis pedis lebeny az extensor digitorum longus ínnal (6) és az anterolateralis comb (ALT) vascularizált lebeny fascia latával (7), mint szabad kompozit szöveti transzplantáció.

Nagyon kevés az irodalom a félvastag bőrátültetés alkalmazásáról, az Achilles ín feletti defektusok fedésére. Attinger és munkatársai (2) véleménye szerint, a sebalap megfelelő gondozása mellett granulációs szövet alakul ki az inak felett. Megállapították, hogy megfelelően előkészített sebalap esetén a félvastag bőrátültetés ugyanolyan sikeres lehet, mint a lokális vagy szabad lebenyek az Achilles-ín feletti defektusok fedésében. A vákuumkezelés alkalmazása a félvastag bőrátültetés felhelyezése előtt nagyon fontos, mivel gyorsítja a granulációs szövet kialakulását $(1,9)$, illetve lényegesen csökkenti a szeptikus szövődmények lehetőségét.
Esetünknél a tumor eltávolítása után, az Achilles ín feletti defektus fedésére három megoldás jött szóba: érnyeles miokután szabad lebenyplasztika, keresztezett végtag lebenyplasztika, illetve félvastag bőrátültetés vákuumkezelés mellett.

Szabad lebeny átültetésre, a rossz vérkeringési viszonyok miatt nem volt lehetőség. A plasztikai sebész véleménye szerint nem volt jó recipiens ér, emiatt a lebeny túlélése kérdéses volt. A keresztezett végtag lebenyplasztika a 63 éves beteg számára igen megterhelő, 3-4 hétig ágyban fekvést és immobilizációt jelent, emellett ellenoldali térdízületi kontraktúra is kialakulhat. A hosszú fekvés miatt mélyvénás trombózis, tüdőembólia, tüdőgyulladás is jelentős rizikótényezőként szerepelnek.

Megítélésünk szerint esetünknél a siker titka az volt, hogy az íntükör alatt már ebben a magasságban soleus izmot találtunk, így az ín hosszanti bemetszései után lehetőség nyílt az izomban lévő pluripotens őssejtek számára, hogy az íntükörre vándorolva ott egy megfelelő granulációs szövetréteg alakuljon ki, amelyre már ráhelyezhető volt a félvastag bőr. Mindezt nagyban elősegítette a vákuumkezelés, a beteg sem kényszerült ágyban fekvésre, felkelhetett, járhatott vákuum készülékével és gipszkötésével.

A vákuumkezelést tapasztalataink alapján javasoljuk minden poszttraumás, vagy ortopéd sebészi okból létrejött nagyobb, ínnal fedett szöveti defektusok kezelésére. 


\section{IRODALOM}

1. Argenta L. C., Morykwas M. J.: Vacuum-assisted closure: A new method for wound control and treatment. Clinical experience. Ann. Plast. Surg. 1997. 38. (6): 563-576. https://doi.org/10.1097/00000637-199706000-00002

2. Attinger C. E., Ducic I., Hess C. L.: Outcome of skin graft versus flap surgery in the salvage of the exposed Achilles tendon in diabetics versus nondiabetics. Plast. Reconstr. Surg. $2006.117 . \quad$ (7): $2460-2467$. https://doi.org/10.1097/01.prs.0000219345.73727.f5

3. Berthe J. V., Toussaint D., Coessens B. C.: One-stage reconstruction of an infected skin and Achilles tendon defect with a composite distally planned lateral arm flap. Plast. Reconstr. Surg. 1998. 102: 1618-1622. https://doi.org/10.1097/00006534-199810000-00044

4. Fletcher C. D.: The evolving classification of soft tissue tumours - an update based on the new 2013 WHO classification. Histopathology. 2014. 64: 2-11. https://doi.org/10.1111/his.12267

5. Isenberg J. S., Fusi S.: Immediate tendon Achilles' reconstruction with composite palmaris longus grafts. Ann. Plast. Surg. 1995. 34: 209-211. https://doi.org/10.1097/00000637-199502000-00018

6. Kim S. W., Hong J. P., Lee W. J., Chung Y. K., Tark K. C.: Single-stage Achilles tendon reconstruction using a composite sensate free flap of dorsalis pedis and tendon strips of the extensor digitorum longus. Ann. Plast. Surg. 2003. 50. (6): 653-657. https://doi.org/10.1097/01.sap.0000041479.79049.71

7. Lee Y. K., Lee M.: Treatment of infected Achilles tendinitis and overlying soft tissue defect using an anterolateral thigh free flap in an elderly patient: A case report. Medicine (Baltimore). 2018. 97. (35): e11995. https://doi.org/10.1097/md.0000000000011995

8. Moghaddam M. A., Perlaky T., Kovács K., Kiss J., Szalay K., Antal I., Sápi Z., Szendrői M.: Epidemiology of soft tissue sarcomas in a university center in Hungary. Magy. Onkol. 2017. 61. (4): 368-373.

9. Morykwas M. J., Argenta, L. C., Shelton-Brown, E. I., McGuirt W.: Vacuum assisted closure: A new method for wound control and treatment. Animal studies and basic foundation. Ann. Plast. Surg. 1997. 38. (6): $553-562$. https://doi.org/10.1097/00000637-199706000-00001

10. Ring A., Kirchhoff P., Goertz O., Behr B., Daigeler A., Lehnhardt M., Harati K.: Reconstruction of soft-tissue defects at the foot and ankle after oncological resection. Front. Surg. 2016. 3. 15. https://doi.org/10.3389/fsurg.2016.00015

11. Stiller C. A., Trama A., Serraino D., Rossi S., Navarro C., Chirlaque M. D., Casali P. G.: Descriptive epidemiology of sarcomas in Europe: Report from the RARECARE project. Eur. J. Cancer. 2013.49. (3): 684-695. https://doi.org/10.1016/i.ejca.2012.09.011

\section{Dr. Moghaddam Amin Maysam}

Semmelweis Egyetem, Ortopédiai Klinika

1082 Budapest, Üllói út 78/b.

E-mail: dr.ma.maysam@gmail.com

Mobil: +36 206663834 